\title{
GENEZA KRYZYSU HIPOTECZNEGO W USA Z PERSPEKTYWY DEKADY
}

\section{WPROWADZENIE}

U schyłku pierwszej dekady XXI w. doszło do kryzysu na niespotykaną od wielu lat skalę. Komisja Nadzoru Finansowego w raporcie z 2010 r. stwierdziła: „Następstwa upadku banku inwestycyjnego Lehman Brothers zgodnie określa się jako najpoważniejszy globalny kryzys finansowy po II wojnie światowej”" Paul Krugman bardzo celnie podkreślił, że jeszcze kilka lat wcześniej panował wielki optymizm związany z osiagnięciem stabilnej sytuacji gospodarczej². Robert Lucas, przemawiając na spotkaniu Amerykańskiego Stowarzyszenia Ekonomicznego, wyraził opinię, że główny problem związany z zapobieganiem kryzysom został rozwiązany oraz że nadszedł czas, by skupić się na długoterminowym wzroście gospodarczym, a nie na wyrównywaniu przebiegu cykli koniunkturalnych ${ }^{3}$. Również Ben Bernanke w 2004 r. entuzjastycznie wyraził się o osiagnnięciu stanu ograniczenia zmienności produkcji i inflacji znanego jako The Great Moderation ${ }^{4}$. Kryzys nie wybuchł jednak bez zapowiedzi. Joseph Stiglitz stwierdził, że ,jedynym zaskakującym aspektem kryzysu gospodarczego

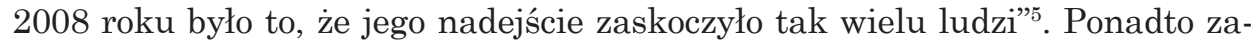
uważył on, że jest to pierwszy od czasów wielkiego kryzysu z lat trzydziestych XX w. przypadek, że Stany Zjednoczone „wyeksportowały poważny kryzys”.

Celem niniejszego artykułu jest przedstawienie obecnego stanu wiedzy na temat rzeczywistych przyczyn i mechanizmów kryzysu hipotecznego w USA. W szczególności staram się wykazać, że wiele spośród problemów, które doprowadziły do wybuchu kryzysu, nie zostało w satysfakcjonujący sposób rozwiązanych w minionej dekadzie i nadal stanowią one zagrożenie dla stabilności systemu finansowego na świecie. Część II przedstawia systematykę czynników odpowiedzialnych za kryzys, natomiast części III-VIII stanowią rozwinięcie opisu tych zjawisk. Część IX zawiera podsumowanie.

${ }^{1} \mathrm{KNF}$, Polski rynek finansowy w obliczu kryzysu finansowego w latach 2008-2009, Warszawa 2010, s. 2.

${ }^{2}$ P. Krugman, Powrót recesji: kryzys roku 2008, tłum. M. Ruszczyński, Wolters Kluwer, Warszawa 2012, s. 15 .

${ }^{3}$ R. Lucas, Macroeconomic priorities, „The American Economic Review” 93(1), 2003, s. 1.

${ }^{4}$ B. Bernanke, The Great Moderation, Remarks by Governor Ben S. Bernanke at the Meetings of the Eastern Economic Association, 2004.

${ }^{5}$ J. Stiglitz, Freefall: jazda bez trzymanki: Ameryka, wolne rynki i tonięcie gospodarki światowej, tłum. A. Gąsior-Niemiec, PTE, Warszawa 2010, s 1. 


\section{BEZPOŚREDNIE PRZYCZYNY WYSTĄPIENIA KRYZYSU}

Kryzys finansowy, który rozpoczął się w 2007 r. w USA, zwany jest również kryzysem hipotecznym lub kryzysem subprime (subprime mortgage crisis). Ekonomiści wskazuja na endogeniczny charakter tego kryzysu, gdyż wiele jego przyczyn wynika ze struktury i mechanizmów gospodarki rynkowej ${ }^{6}$. Identyfikacja czynników, które przyczyniły się do wybuchu kryzysu, była szeroko analizowana i komentowana w literaturze. Genezę kryzysu opisywali m.in. Charles Goodhart ${ }^{7}$, Olivier Blanchard ${ }^{8}$, Dariusz Rosati ${ }^{9}$, John Taylor ${ }^{10}$, a jego konsekwencje np. Andrzej Sławiński ${ }^{11}$.

Powołując się na raport Komisji Europejskiej ${ }^{12}$, Michał Konopczak, Rafał Sieradzki i Michał Wiernicki ${ }^{13}$ wskazali na następujące źródła kryzysu o charakterze makroekonomicznym i mezoekonomicznym:

- narastanie globalnych nierównowag;

- utrzymywanie niskiego poziomu stóp procentowych w krajach rozwiniętych, związane z okresem uspokojenia na rynkach finansowych, ożywienia gospodarczego i relatywnie niskiej stopy inflacji (The Great Moderation);

- rozwój i wzrost znaczenia rynków finansowych;

- model nadzoru oparty na zasadzie samoregulacji rynków finansowych;

- sytuacja na rynku nieruchomości w USA.

Kolejne przyczyny kryzysu miały charakter mikroekonomiczny lub stricte finansowy:

- model funkcjonowania banków, w którym wykorzystywały one sekurytyzację aktywów i kredytowe instrumenty pochodne;

- rozwój inżynierii finansowej i powstanie skomplikowanych, trudnych do wyceny instrumentów finansowych;

- konflikt interesów w agencjach ratingowych, które doradzały bankom w projektowaniu nowych produktów finansowych, a zarazem nadawały tym produktom oceny;

- model finansowania, polegajacy na finansowanie długoterminowych aktywów z użyciem krótkoterminowych pożyczek;

${ }^{6}$ M. Burzała, Wybrane metody badania efektów zarażania na rynkach kapitałowych, Wyd. UEP, Poznań 2014, s. 27.

${ }^{7}$ Ch. Goodhart, Kryzys finansowy i przyszłość systemu finansowego, „Zeszyty BRE Bank CASE", nr 100, Warszawa 2009.

${ }^{8}$ O. Blanchard, The crisis: basic mechanisms, and appropriate policies, „IMF Working Paper", no. 09/80, 2009.

${ }_{9}$ D. Rosati, Przyczyny i mechanizm kryzysu finansowego w USA, „Ekonomista” 2009, nr 3.

10 J. Taylor, Zrozumieć kryzys finansowy: przyczyny, skutki, interpretacje, tłum. Ł. Goczek, WN PWN, Warszawa 2010.

${ }_{11}$ A. Sławiński, Wpływ globalnego kryzysu bankowego na bankowość centralna, „Ekonomista” 2010, nr 2.

${ }^{12}$ Komisja Europejska, Economic crisis in Europe: causes, consequences and responses, „European Economy" 2009, no. 7.

${ }^{13}$ M. Konopczak, R. Sieradzki, M. Wiernicki, Kryzys na światowych rynkach finansowych wptyw na rynek finansowy w Polsce oraz implikacje dla sektora realnego, „Bank i Kredyt” 41, 2010, nr 6, s. 47. 
- niska przejrzystość i asymetria informacji na niektórych rynkach finansowych;

- rozrost instytucji finansowych oraz zwiększenie współzależności między nimi, jak również wykorzystywanie przez nie nadmiernej dźwigni finansowej.

Kryzys miał również wiele przyczyn natury psychologicznej. Adam Szyszka $^{14}$ do behawioralnych przyczyn kryzysu zaliczył: chciwość inwestorów i zarządzajacych, niedoszacowanie ryzyka, zachowania stadne, ograniczona racjonalność i błędy agencji ratingowych oraz strach.

\section{GLOBALNA NIERÓWNOWAGA I POLITYKA SYSTEMU REZERWY FEDERALNEJ W LATACH 2001-2007}

W 2006 r. w artykule poświęconym nierównowadze globalnej Michał Rubaszek stwierdził: „wielu ekonomistów wskazuje, że gospodarka światowa nie znajduje się obecnie w stanie równowagi" ${ }^{15}$. Z perspektywy czasu zdanie to można uznać za prorocze. Bardzo często do grona czynników, które przyczyniły się do wybuchu kryzysu, zalicza się globalne zmiany rozkładu sił gospodarczych na świecie i towarzysząca im nierównowagę ${ }^{16}$. Sytuację tę najlepiej obrazuje porównanie nadwyżki w saldzie obrotów bieżących krajów Dalekiego Wschodu z deficytem obrotów bieżących Stanów Zjednoczonych. W gospodarce światowej coraz większe znaczenie zyskują takie kraje, jak Chiny i Indie, podczas gdy tempo wzrostu PKB w USA i w Europie jest niskie.

Do przyczyn narastającej nierównowagi globalnej zaliczyć można ${ }^{17}$ :

- utrzymujący się wysoki poziom deficytu budżetowego w USA, odpowiedzialny za zjawisko bliźniaczych deficytów;

- politykę kursową krajów Dalekiego Wschodu;

- trwały długookresowy wzrost produktywności w USA wywołujący skłonność do utrzymywania aktywów amerykańskich w portfelach inwestycyjnych;

- nadmierny poziom globalnych oszczędności netto, powodowany w szczególności azjatycką kulturą oszczędności oraz wzrostem cen ropy naftowej.

Deficyt salda obrotów bieżących w USA wynikł zarówno z niskiego poziomu oszczędności w gospodarce, jak i ze sprzyjającej polityki makroekonomicznej. Jednocześnie rola dolara jako waluty rezerwowej stanowi czynnik sprzyjajacy emisji nisko oprocentowanych papierów wartościowych denominowanych $\mathrm{w}$ tej walucie. Z kolei strategia rozwoju opartego na eksporcie i samofinansowaniu się chińskich przedsiębiorstw sprzyja akumulacji przepływów dolarowych w Chinach. Amerykańska kultura życia na kredyt i azjatycka kultura

${ }_{14}$ A. Szyszka, Behawioralne aspekty kryzysu finansowego, „Bank i Kredyt” 40, 2009, nr 4, s. $14-25$.

${ }^{15}$ M. Rubaszek, Nierównowaga globalna: przyczyny oraz możliwe rozwiazania, „Bank i Kredyt" 37, 2006, nr 7, s. 18.

${ }^{16}$ Por. W. Orłowski, Dziesięć przyczyn kryzysu i ich analiza, w: J. Szambelańczyk (red.), Globalny kryzys finansowy $i$ jego konsekwencje $w$ opiniach ekonomistów polskich, ZBP, Warszawa 2009, s. 8; Komisja Europejska, op. cit., s. 46.

${ }^{17}$ M. Rubaszek, op. cit., s. 18. 
oszczędzania okazały się wobec siebie komplementarne. Dodatkowo wiele krajów rozwijajacych się utrzymywało sztywny kurs walutowy wobec dolara na poziomie niedowartościowującym lokalne waluty. Działo się tak, gdyż kraje te wspierały eksport $\mathrm{w}$ gospodarkach lub starały się podnieść poziom rezerw walutowych. Sytuację w globalnej gospodarce dopełniło utrzymywanie ekspansywnej polityki monetarnej w USA przed kryzysem, co zwiększyło prawdopodobieństwo tworzenia się baniek spekulacyjnych ${ }^{18}$.

Począwszy od lat dziewięćdziesiątych XX w. Stany Zjednoczone cieszyły się korzystnymi warunkami makroekonomicznymi. Wzrost gospodarczy utrzymywał się na dodatnim poziomie przez blisko dwie dekady, niekiedy osiagając poziom 2-3\% rocznie ${ }^{19}$. W tym samym czasie inflacja kształtowała się na niskim poziomie. Ekonomiści nazywają ten okres Wielkim Umiarkowaniem - The Great Moderation. Powszechny optymizm sprzyjał przekonaniu o niskim ryzyku i był powodem, dla którego polityka monetarna w USA stała się nadmiernie ekspansywna. J. Taylor wskazał politykę Systemu Rezerwy Federalnej (SRF, Rezerwa Federalna) jako główną przyczynę boomu i załamania, które po nim nastapiło ${ }^{20}$. Skonstruował on scenariusz alternatywny, zgodnie z którym bańki spekulacyjnej i kryzysu można było uniknąć, gdyby SRF zaczą podnosić stopę procentowa już w $2002 \mathrm{r}$. zgodnie z zaleceniami reguły Taylora. Wdrożona przez Rezerwę Federalną polityka pieniężna znacznie odchylała się od reguły Taylora i odpowiadała za nadmiar pieniądza na rynku ${ }^{21}$.

W 1999 r. wzrastająca inflacja wpłynęła na ciąg decyzji FOMC ${ }^{22}$ zwiększajacych podstawowa stopę procentową. W ten sposób stopa funduszy federalnych osiagnęła 16 maja 2000 r. poziom 6,5\%. Strategia amerykańskiej polityki monetarnej ukształtowana była wtedy przez przekonanie, że pęknięcie bańki spekulacyjnej rzadko prowadzi do dotkliwej recesji, wobec czego należy reagować szybkimi obniżkami stóp dopiero po załamaniu cen ${ }^{23}$. Alan Greenspan, kierując się tą doktryna, nie podnosił stóp procentowych w drugiej połowie lat dziewięćdziesiątych, mimo spekulacji na wzrost cen akcji ${ }^{24}$. Pomimo reakcji Rezerwy Federalnej recesja nastapiła w latach 2001-2002. Między rokiem 2001 a 2004 główna stopa procentowa została obniżona z 6,5\% do 1\%. Niski poziom krótkoterminowych stóp procentowych wpłyną na nasilenie presji inflacyjnej. Dlatego w 2004 r. SRF zaczął stopniowo podwyższać stopę funduszy federalnych. Zacieśnianie polityki pieniężnej zakończyło się 29 czerwca 2006 r. Stopa procentowa wynosiła wtedy $5,25 \%$.

\footnotetext{
${ }^{18}$ Komisja Europejska, op. cit., s. 47.

${ }^{19}$ W. Nawrot, Globalny kryzys finansowy XXI wieku: przyczyny, przebieg, skutki, prognozy, CeDeWu, Warszawa 2009, s. 57.

${ }^{20}$ J. Taylor, op. cit., s. 23-29.

${ }^{21}$ Poziom stopy funduszy federalnych znajdował się od 2002 do 2006 r. poniżej poziomu wskazanego reguła Taylora, czyli poziomem wyznaczonym przez neutralne nastawienie polityki pieniężnej.

${ }^{22}$ Federal Open Market Committee - Federalny Komitet do spraw Operacji Otwartego Rynku - organ decydujący o polityce pieniężnej w USA.

${ }^{23}$ Zapowiedź szybkiej obniżki stóp po załamaniu rynku nazywano Greenspan put - opcją chroniąca przed recesja.

${ }^{24}$ Bańka spekulacyjna na akcjach firm z branży informatycznej (tzw. dotcomów).
} 
Utrzymywanie w latach 2001-2004 krótkoterminowych stóp procentowych na poziomie niższym niż $2 \%$ miało istotne konsekwencje dla systemu bankowego. Niski zwrot oferowany przez bezpieczne instrumenty finansowe motywował inwestorów (i banki) do poszukiwania bardziej ryzykownych inwestycji oferujących wyższy zwrot. Zachęciło to banki do udzielania kredytów klientom o niskiej zdolności kredytowej ${ }^{25}$. Nastapił więc wzrost akcji kredytowej banków, któremu nie towarzyszył wzrost ilości zgromadzonych przez banki depozytów - stopy procentowe nie zachęcały bowiem do oszczędzania. W konsekwencji rozwinęła się strategia biznesowa „udzielasz i uciekasz” (originate-to-distribute), zgodnie z którą banki intensywnie stosowały sekurytyzację swoich aktywów ${ }^{26}$. Ch. Goodhart podkreślił, że w tym okresie panowało powszechne przekonanie, że stopy procentowe będą utrzymywać się na niskim poziomie przez dłuższy okres, a ryzyko zostało wyeliminowane ${ }^{27}$. Działania SRF były więc przyczyną większego korzystania z dźwigni finansowej, niż gdyby zaistniały inne okoliczności. Ponadto niskie stopy procentowe wpłynęły na podwyższenie zdolności kredytowej klientów banków.

Dziesięć lat po wystapieniu pierwszych objawów kryzysu nadal powinniśmy mieć na uwadze powyższe okoliczności. Czynniki stojące u podstaw globalnej nierównowagi nie zostały przezwyciężone. Zadłużenie Stanów Zjednoczonych nie maleje, a przedwyborcze obietnice polityczne moga je jedynie zwiększyć. Nie można również liczyć na to, że działania krajów Dalekiego Wschodu (np. decyzje dotyczące polityki kursowej) przyczynią się do zmniejszenia nierównowagi. Nie można również wykluczyć wystapienia kolejnych baniek spekulacyjnych na rynku amerykańskim. Można jedynie liczyć na to, że podwyżki stóp procentowych (obecnie bliskich 0\%) przez Rezerwę Federalną będą dokonywane stopniowo, a nie gwałtownie - jak w latach 2004-2006. Ponadto działalność banków jest obecnie bardziej kontrolowana.

\section{SYTUACJA NA RYNKU NIERUCHOMOŚCI I POLITYKA MIESZKANIOWA W USA}

Jak podkreślił Ch. Goodhart przeciętne ceny nieruchomości od 1946 r. (aż do momentu nadejścia kryzysu) nigdy nie spadały - znajdowały się w ciagłym trendzie rosnacym ${ }^{28}$. Ekstrapolacja tego trendu dała podstawę do prognozowania dalszych wzrostów cen. Gdyby wartość nieruchomości stanowiących zabezpieczenia kredytów hipotecznych rosła bez końca, można by uniknąć kryzysu. Systematyczny wzrost cen nieruchomości napędzany był przez przyspieszanie

${ }^{25}$ I. Pszczółka, Amerykański „kryzys hipoteczny”, w: J. Kaliński, M. Zalesko (red.), Od wielkiego kryzysu gospodarczego do wielkiego kryzysu finansowego: perturbacje $w$ gospodarce światowej w latach 1929-2009, Wyd. UwB, Białystok 2009, s. 392.

${ }^{26}$ J. Pruski, Banki centralne w obliczu kryzysu na światowych rynkach finansowych - wnioski dla Polski, w: E. Balcerowicz (red.), Zaburzenia na światowych rynkach a sektor finansowy w Polsce, Zeszyty BRE Bank - CASE, nr 96, Warszawa 2008, s. 10.

27 Ch. Goodhart, op. cit., s. 13.

28 Ibidem, s. 13-15. 
zakupu nieruchomości celem bądź zabezpieczenia się przed dalszym wzrostem cen, bądź wykorzystania trendu i spekulacji. Dynamiczny rozwój rynku nieruchomości nakręcał koniunkturę również w innych sektorach gospodarki i prowadził do poczucia bogacenia się społeczeństwa.

Pogłębioną analizę amerykańskiego rynku nieruchomości zamieszcza w swojej pracy Wioletta Nawrot ${ }^{29}$. Liczba sprzedawanych w USA nieruchomości dwukrotnie wzrosła między początkiem lat dziewięćdziesiątych XX a połową pierwszej dekady XXI w. Dynamika wzrostu sprzedaży domów była znaczaça, aż do 2005 r., gdy liczba sprzedawanych domów zaczęła powoli maleć. $\mathrm{W}$ analogicznym okresie wartość sprzedaży domów wzrosła przeszło pięciokrotnie. Na dynamice wzrostu wartości domów zaważył przede wszystkim wzrost ich cen. Zmiany cen na rynku nieruchomości ilustruje wskaźnik HPI (House Price Index) ogłaszany przez Federalna Agencję Finansowania Nieruchomości (Federal Housing Finance Agency). Szybkie tempo wzrostu cen nieruchomości zaobserwować można na wykresie 1 .

Wykres 1

Indeks cen domów (HPI) w latach 1995-2014 oraz dynamika zmian HPI

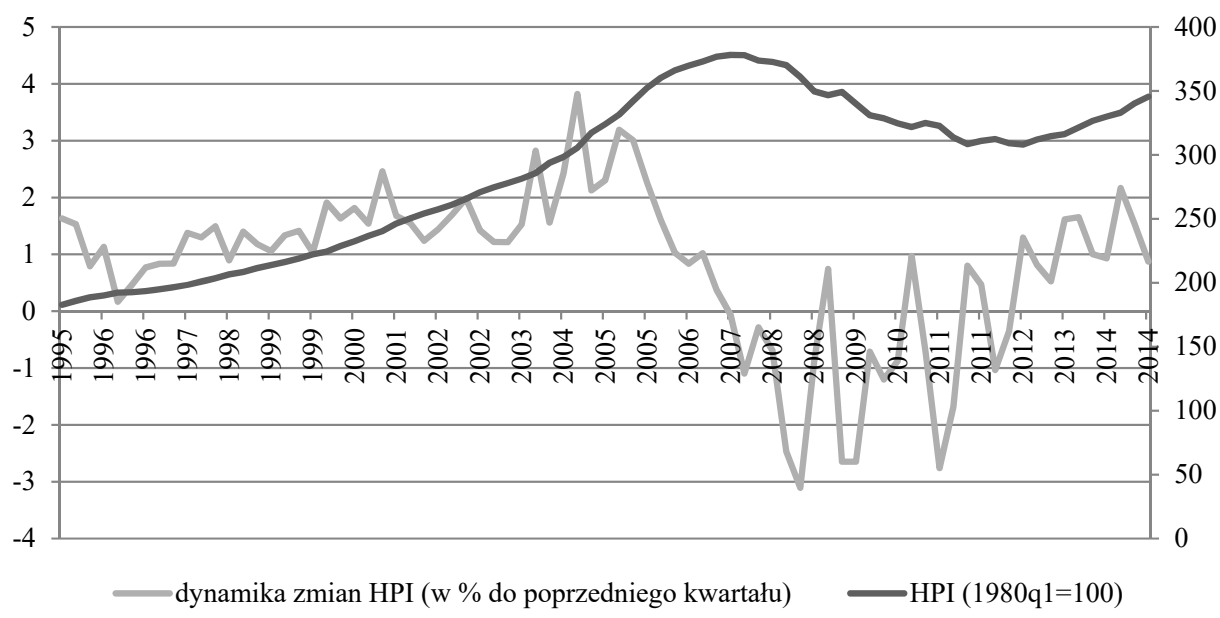

Źródło: opracowanie na podstawie https://research.stlouisfed.org/fred2 [dostęp: 8.10. 2016].

W latach 1993-2005 zmiany cen charakteryzował trend wzrostowy, który uwidocznił się szczególnie po 1998 r. Ostatni znaczący wzrost nastapił w pierwszym kwartale 2005 r., gdy ceny wzrosły o $3 \% \mathrm{w}$ stosunku do poprzedniego kwartału. Od 2005 do 2007 r. ceny transakcyjne nieruchomości wzrastały coraz wolniej, w niektórych miesiącach 2006 nawet spadając, aż w pierwszym kwartale 2007 kwartalna dynamika osiagnęła wartość ujemną. W 2008 r. utrata wartości nieruchomości była już znaczne.

${ }^{29}$ W. Nawrot, op. cit., s. 41-57. 
Wraz z rozwojem rynku nieruchomości rozrósł się również rynek kredytów hipotecznych. A. Greenspan tłumaczył brak reakcji Rezerwy Federalnej na rosnacy udział kredytów o wysokim stopniu ryzyka przewagą korzyści związanych z poparciem społecznym dla liberalnej gospodarki rynkowej, wynikającym ze wzrostu odsetka osób posiadających własne domy ${ }^{30}$. Pod koniec 2005 r. wartość udzielonych kredytów hipotecznych wyniosła 69,4\% PKB Stanów Zjednoczonych w 2005 r. Doprowadzało to ciagłego wzrostu wskaźnika posiadania nieruchomości w USA, który gwałtownie spadł w 2008 r. w wyniku kryzysu finansowego ${ }^{31}$.

Rozwój budownictwa mieszkaniowego stanowił priorytet amerykańskiej polityki od czasów programu New Deal prezydenta Roosevelta ${ }^{32}$. W 1977 r. w USA uchwalono Community Reinvestment Act (CRA) - ustawę majacca zapewnić wzrost udzielonych kredytów hipotecznych przez banki komercyjne i wesprzeć budownictwo mieszkaniowe. CRA zobowiązywała banki do udzielania kredytów w rejonach charakteryzujących się niskimi dochodami. Polityka kredytowa banków podlega od tego czasu nadzorowi, a działania uznane za przejaw dyskryminacji moga podlegać karom finansowym, nałożonym zgodnie z Equal Credit Opportunity Act. Nowelizacja ustawy CRA z 1995 r. pozwoliła na sekurytyzację portfela kredytów o wysokim ryzyku, wspierając rozwój rynku papierów wartościowych. Ponadto w 1999 r. uchwalono Gramm-Leach-Bliley Act, który zniósł Glass-Steagall Act ${ }^{33}$ oraz doprowadził do znacznej deregulacji systemu finansowego ${ }^{34}$.

Rozwój rynku nieruchomości wspierany był przez władze amerykańskie przez utworzenie takich instytucji, jak Rządowe Stowarzyszenie Krajowej Hipoteki (GNMA, zwane też Ginnie Mae), Fannie Mae oraz Freddie Mac ${ }^{35}$. Pierwsza z nich jest agencja federalna, a pozostałe są sponsorowanymi z funduszy federalnych korporacjami prywatnymi (GSE - Government Sponsored Enterprises). Dostarczają one środków pieniężnych na rynek kredytów hipotecznych przez sprzedaż obligacji i zakup hipotek za uzyskane sumy ${ }^{36}$.

Kryzys finansowy wywołał załamanie cen na rynku nieruchomości i spadek wartości zadłużenia hipotecznego na rynku amerykańskim. Jednakże od

30 A. Sławiński, Przyczyny globalnego kryzysu bankowego, w: J. Osiński, S. Sztaba (red.), Nauki społeczne wobec kryzysu na rynkach finansowych, SGH Oficyna Wydawnicza, Warszawa 2009, s. 38 .

31 A. Bojanowska, Historyczne uwarunkowania światowego rozwoju bankowości hipotecznej, w: A. Szelagowska (red.), Wspótczesna bankowość hipoteczna, CeDeWu, Warszawa 2010, s. 21-22.

32 Elementem programu New Deal było powołanie w 1938 r. do życia instytucji Fannie Mae. Freddie Mac funkcjonuje od 1970 r.

${ }^{33}$ Obowiąująca od 1933 r. ustawa Glass-Steagall Act była w USA przyczyną odseparowania bankowości komercyjnej i inwestycyjnej (B. Samojlik, Kryzys finansowy: źródta, skutki, kierunki naprawy, w: J. Osiński, S. Sztaba (red.), Nauki społeczne wobec kryzysu na rynkach finansowych, SGH Oficyna Wydawnicza, Warszawa 2009, s. 62).

${ }^{34}$ B. Samojlik, op. cit., s. 59-63; W. Nawrot, op. cit., s. 72-73.

35 Fannie Mae (Federal National Mortgage Association) i Freddie Mac (Federal Home Loan Mortgage Corporation) zostały powołane z misją umożliwienia rodzinom pracującym dostępu do długoterminowych kredytów hipotecznych.

${ }^{36}$ F. Mishkin, Ekonomika pieniqdza, bankowości i rynków finansowych, tłum. A. Mincewicz, WN PWN, Warszawa 2002, s. 439. 
przełomu 2012 i 2013 r., poziom obu tych wskaźników ponownie rośnie. Ceny nieruchomości znajduja się w 2016 r. na poziomie sprzed kryzysu. Wartość zadłużenia rośnie wraz z cenami kupowanych mieszkań. Kontynuacja tych trendów może sprzyjać pojawieniu się kolejnej bańki spekulacyjnej na rynku nieruchomości, a ewentualna podwyżka oprocentowania kredytów może negatywnie zrewidować zdolność kredytową dłużników.

\section{ROZWÓJ SEKTORA FINANSOWEGO I NADZÓR NAD RYNKAMI}

Przed wybuchem kryzysu panowało przekonanie, że deregulacja rynków finansowych sprzyja rozwojowi gospodarki. Liczne badania potwierdzające tezę o korzystnym wpływie rozwoju sektora finansowego na wzrost gospodarczy znaleźć można w pracy Rossa Levine'a ${ }^{37}$. Bankructwa instytucji finansowych oraz straty spowodowane spadkiem cen instrumentów finansowych sprawiły, że wiele osób dostrzegło błędy w dotychczasowej polityce regulacji sektora finansowego. Podczas przesłuchania przez komisję Izby Reprezentantów w 2008 r. A. Greenspan przyznał, że jego wiara w to, że instytucje kredytowe, kierowane własnym interesem, zapewnią ochronę kapitału akcjonariuszy, była błędem ${ }^{38}$. Niektóre opinie krytyków liberalizacji rynków były szczególnie ostre, np. stanowisko prezydenta Niemiec Horsta Köhlera, który stwierdził, że „rynki finansowe stały się potworem, którego należy poskromić”39.

Gerald Epstein zauważył, że w przeciagu ostatnich trzydziestu lat gospodarki uległy wielkim zmianom: rola rządów zmalała, a rola rynków wzrosła; wzrosła wymiana handlowa oraz wartość przepływów kapitałowych między krajami. Za wspomniane zmiany odpowiadaja trzy procesy i doktryny: neoliberalizm, globalizacja i finansyzacja. Zjawisko finansyzacji (financialization) nie ma jeszcze jednoznacznej definicji. Epstein określił je jako rosnącą rolę motywów finansowych, rynków finansowych, podmiotów finansowych i instytucji finansowych w działaniu krajowych i międzynarodowych gospodarek ${ }^{40}$.

Statystyki bezwzględnie potwierdzają fakt znacznego wzrostu rynków finansowych. Najwyższe wartości mierniki osiagnęły bezpośrednio przed wybuchem kryzysu. Wartość aktywów finansowych wzrosła w skali globalnej ze $120 \%$ PKB w 1980 r. do $355 \%$ PKB w 2007 r. Istnieje duża rozbieżność danych w zależności od grupy państw, którą badamy. W gospodarkach rozwiniętych wartość aktywów finansowych w odniesieniu do PKB w 2007 r. wyniosła $417 \%$, natomiast w krajach rozwijających się $-199 \%{ }^{41}$.

W raporcie o stabilności systemu finansowego z 2012 r. NBP wskazuje, że eskalacja zaburzeń na rynkach finansowych „ujawniła słabości regulacyjne

${ }^{37}$ R. Levine, Financial development and economic growth: views and agenda, ,Journal of Economic Literature" 35, 1997. 2008.

${ }^{38}$ E. Andrews, Greenspan concedes error on regulation, „The New York Times”, October 23,

${ }^{39}$ D. Scally, Köhler attacks financial market 'monster', „The Irish Times”, May 15, 2008.

${ }^{40}$ G. Epstein, Financialization and the World Economy, Northampton 2005, s. 3.

${ }^{41}$ S. Lund et al., Financial globalization: Retreat or reset? Global Capital Markets 2013, 2013, s. 2. 
i związaną z nimi niedostateczną przejrzystość rynków oraz występowanie w obrocie zbyt złożonych instrumentów” ${ }^{42}$. Czynnikiem odpowiedzialnym za brak przejrzystości rynków było również przesuwanie części działalności bankowej do podmiotów nieregulowanych. Proces ten prowadzi do wykształcenia równoległego systemu bankowego, tzw. shadow banking, który nie podlega nadzorowi i regulacjom ostrożnościowym ${ }^{43}$. Cytując Radę Stabilności Finansowej (Financial Stability Board), NBP podaje, że wartość globalnego sektora shadow banking wzrosła z 27 bln USD w 2012 r. do 60 bln USD w 2007 r. Odpowiadało to połowie wartości aktywów tradycyjnego systemu bankowego. Jason Hsu i Max Moroz sformułowali tezę, że bankowość równoległa narastała lawinowo przed kryzysem oraz że zaburzenia w tych instytucjach były ważnym czynnikiem potęgującym straty w systemie finansowym w czasie kryzysu ${ }^{44}$.

W 2007 r. IMF, publikując coroczny raport dotyczący stabilności finansowej, dużo uwagi poświęcił brakowi dyscypliny na dojrzałych rynkach finansowych w krajach rozwiniętych. Umieścił tam również rekomendację dla krajów rozwijających się, by zwiększyły nadzór nad rynkami finansowymi oraz instytucjami kredytowymi ze względu na ich podatność na zaburzenia. Wskazano na pięć obszarów problemowych w państwach rozwijajacych się ${ }^{45}$ : rosnący rynek sprzedaży aktywów kredytowych w ramach subskrypcji prywatnej; krajowe banki w coraz większym stopniu pozyskują finansowanie na rynkach międzynarodowych, by sfinansować rosnaccą akcję kredytową w kraju; przedsiębiorstwa angażują się w zewnętrzne finansowanie oparte na regułach podobnych do carry trade; instytucje finansowe coraz aktywniej używają strukturyzowanych lub syntetycznych instrumentów finansowych, by zwiększyć zyski; zagraniczni inwestorzy kapitałowi mogą zwiększyć ryzyko zmienności cen i przewartościowania aktywów kapitałowych.

Jak zauważyli Donato Masciandaro, Rosaria Pansini, Marc Quintyn, błędy $\mathrm{w}$ regulacji sektora finansowego były często wskazywane w literaturze jako czynnik sprzyjający wybuchowi kryzysu ${ }^{46}$. Niekiedy również wskazuje się na błędy w nadzorze (jego architekturze bądź zarządzaniu nim) i ich wpływ na kryzys. Dokonując przeglądu badań, autorzy wskazują na dwa artykuły, w których podano specyficzne przykłady popełnionych błędów. Axel Leijonhufvud postawił tezę, że system nadzoru w USA był zbyt rozczłonkowany, by poprawnie monitorować zintegrowane i współzależne instytucje systemu finansowego $^{47}$. Willem Buiter argumentował, że Bank Anglii nie posiadał wystarczają-

${ }^{42}$ NBP, Raport o stabilności systemu finansowego. Lipiec 2012 r., Warszawa 2012, s. 62.

${ }^{43}$ Szerokie ujęcie zjawiska shadow banking jako systemowej innowacji finansowej znaleźć można w monografii J. Solarza Shadow banking: systemowa innowacja finansowa, Społeczna Akademia Nauk w Łodzi, Łódź-Warszawa 2014.

${ }_{44}$ J. Hsu, M. Moroz, Shadow banks and the financial crisis of 2007-2008, w: G. Gregoriou (ed.), The Banking Crisis Handbook, 2010.

${ }_{45}$ IMF, Global Financial Stability Report. Market Developments and Issues, Washington, DC, 2007, s. 22.

${ }^{46}$ D. Masciandaro, R. Pansini, M. Quintyn, The Economic Crisis: Did Financial Supervision Matter, ,Working Paper”, no. 11/261, International Monetary Fund 2011, s. 8.

47 A. Leijonhufvud, Curbing instability: policy and regulation, „CEPR Policy Insight”, no. 36, 2009. 
cych informacji o stanie banku Northern Rock, wobec czego nie zareagował we właściwym momencie udostępnieniem awaryjnej płynności ${ }^{48}$. Ponadto częstym zarzutem stawianym ex post jest brak nadzoru makroostrożnościowego, które to rozwiązanie jest obecnie uważane za błąd w architekturze nadzorczej. Pozostałe błędy w polityce nadzorczej, na które wskazują ekonomiści, to m.in. niewystarczająca niezależność nadzoru, brak mierników odpowiedzialności (accountability), brak odwagi, by drążyć niewygodne kwestie ${ }^{49}$, działanie organów regulacyjnych niezgodne $\mathrm{z}$ interesem publicznym (regulatory capture ${ }^{50}$ oraz brak odpowiedniej wiedzy, by zrozumieć rodzaje ryzyka związane z nowymi operacjami finansowymi. Autorzy konkluduja, że była to, stosowana na wielka skalę, polityka „zamiatania problemów pod dywan”"

Przewidywania dotyczące dalszego rozwoju rynków finansowych sugeruja, że ich rola będzie w najbliższych latach dynamicznie rosła, w szczególności w krajach grupy emerging markets. Zarzuty dotyczące niewystarczającej przejrzystości rynków oraz zbyt złożonych instrumentów są nadal aktualne. Do pozytywnych zmian należy jednak zaliczyć kroki zmierzające do zwiększenia regulacji i nadzoru nad sektorem bankowym. W reakcji na kryzys Bazylejski Komitet Nadzoru Bankowego wypracował nowe standardy w ramach tzw. Basel III. Więcej uwagi poświęcono kwestii zachowania płynności w realiach wahań cyklicznych. Zasady te, choć poddane modyfikacji przez Rezerwę Federalną, obowiązywać będą również w USA. Wadą zasad Bazylei III jest jednak wykorzystywanie do szacowania ryzyka kredytowego ocen agencji ratingowych. W USA pozytywne zmiany wiążą się z wejściem $\mathrm{w}$ życie ustawy Dodda-Franka, która wprowadziła liczne zmiany w zakresie regulacji finansowych.

\section{POLITYKA KREDYTOWA BANKÓW KOMERCYJNYCH I APETYT NA RYZYKO}

Korzystna sytuacja gospodarcza w USA podczas ostatniej dekady przed kryzysem oraz niski poziom oficjalnych stóp procentowych wywołały wśród uczestników rynku finansowego duży optymizm. Klienci banków optymistycznie oceniali swoje szanse na spłatę wysokiego kredytu hipotecznego, a banki komercyjne mniejszą uwagę przykładały do poprawnych procedur oceny ryzyka, przeszacowując zdolność kredytową klientów. Banki miały w tym swój interes - niskie stopy procentowe oznaczały mniejsze możliwości osiagania

${ }^{48}$ W. Buiter, Lessons from the North Atlantic Financial Crisis, Federal Reserve Bank of New York 2008.

49 „[...] lack of audacity to probe or to take matters to their conclusion and to be intrusive" (D. Masciandaro, R. Pansini, M. Quintyn, op. cit., s. 9).

${ }^{50}$ Autorzy odwołują się do teorii regulacji publicznej George'a Stiglera, zgodnie z którą instytucje regulacyjne nie służą interesom ogólnospołecznym, lecz interesom tych grup, które są przedmiotem kontroli.

${ }^{51}$ D. Masciandaro, R. Pansini, M. Quintyn, op. cit., s. 9. 
zysku. W konsekwencji rosła skłonność do ryzyka po obu stronach umowy kredytowej. W wyniku nasycenia rynku tradycyjnych kredytów hipotecznych banki komercyjne otworzyły się na grupę potencjalnych kredytobiorców zwanych ninja (no income, no job, no assets) - klientów bez dochodów, bez pracy, a nawet bez zabezpieczenia, gdyż jako zabezpieczenie traktowano przyszły oczekiwany wzrost wartości nieruchomości. Ze względu na dużo wyższe ryzyko związane z udzielaniem tego typu kredytów oprocentowanie było zazwyczaj wyższe niż w segmencie kredytów prime.

Powyższy mechanizm został dobrze odzwierciedlony w teorii niestabilności systemu finansowego Hymana Minsky’ego. Stwierdził on, że skłonność banków do podejmowania ryzyka rośnie wraz z oddalaniem się w czasie od poprzedniego kryzysu. W procesie tym wyróżnić można trzy fazy. Pierwsza (hedge financing) to okres, w którym banki udzielają kredytów tylko wiarygodnym kredytobiorcom, zdolnym do spłacenia zarówno rat kapitałowych, jak i odsetek. Druga (speculative financing) następuje, gdy banki zaczynaja udzielać kredytów osobom o zmniejszonej zdolności kredytowej, które są zdolne do spłaty odsetek, ale ich zdolność do spłaty rat zależy od utrzymania się dobrej koniunktury i wzrostu dochodów w gospodarce. Trzecia (Ponzi financing) dotyczy okresu, w którym kredyty są udzielane osobom niezdolnym do regulowania zobowiązań (odsetek i rat), ale mają one zabezpieczenie w postaci rosnących w cenie aktywów kapitałowych - najczęściej domów ${ }^{52}$.

Wykres 2 ilustruje wartość zadłużenia gospodarstw domowych w USA z tytułu kredytów hipotecznych. Pomiędzy czwartym kwartałem 2001 a pierwszym kwartałem 2008 r. zadłużenie podwoiło się, osiagając w szczytowym momencie wartość prawie 11 bln USD. Dynamika przyrostu wartości zadłużenia wynosiła ponad 8\% kwartalnie jeszcze w 2006 r., lecz w 2007 wyraźnie spadła, a w 2008 po raz pierwszy od wielu lat zadłużenie zamiast rosnaccé, zaczęło spadać.

Jak podała W. Nawrot, zadłużenie hipoteczne gospodarstw domowych stanowiło w 2008 r. niemal 100\% krajowego PKB, podczas gdy w latach siedemdziesiatych XX w. odpowiadało ono 5\% PKB, a pod koniec lat dziewięćdziesiątych XX w. $-40 \%{ }^{53}$. Wraz ze wzrostem zadłużenia rosły również koszty jego obsługi w odniesieniu do dochodów gospodarstw domowych, co musiało wywołać trudności w obsłudze kredytów, gdy stopy procentowe wzrosły ${ }^{54}$.

Wzrost popytu na kredyty hipoteczne w USA Dariusz Rosati przypisał czterem czynnikom: spadkowi stopy oszczędności w USA, zmianie postawy banków w kwestii udzielania kredytów mniej zamożnym gospodarstwom domowym, spadkowi ceny kredytów oraz wzrostowi oczekiwanej stopy przychodu z inwestycji mieszkaniowych. Średnie oprocentowanie kredytów hipotecznych spadło z około $8 \%$ w 2000 r. do około 5,8\% w latach $2003-2005^{55}$.

\footnotetext{
52 A. Sławiński, Przyczyny globalnego kryzysu bankowego, w: J. Osiński, S. Sztaba (red.), Nauki społeczne wobec kryzysu na rynkach finansowych, SGH Oficyna Wydawnicza, Warszawa 2009, s. 36-37.

${ }^{53}$ W. Nawrot, op. cit., s. 65.

54 W. Nawrot, op. cit., s. 68; D. Rosati, op. cit., 332-333.

${ }_{55}$ D. Rosati, op. cit., s. 327-331.
} 


\section{Wykres 2}

Wartość zadłużenia gospodarstw domowych w USA z tytułu kredytów hipotecznych (w bln USD - lewa oś) i dynamika zmian (w \% - prawa oś)

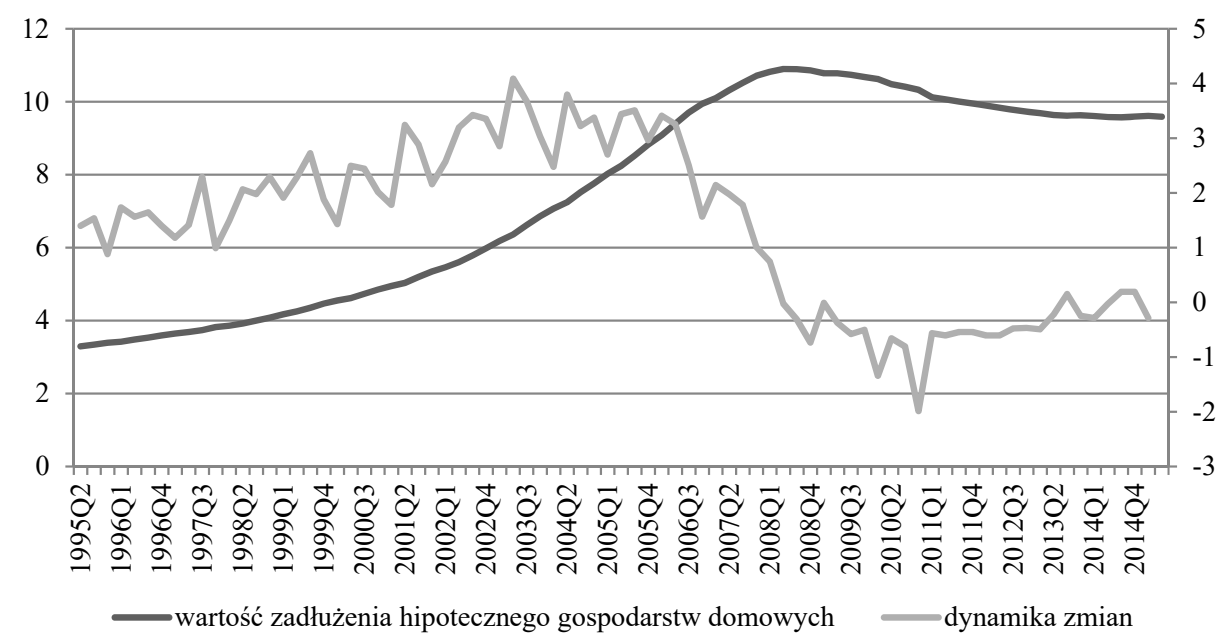

Źródło: opracowanie na podstawie http://www.federalreserve.gov/econresdata/statisticsdata.htm. [dostęp: 8.10.2016].

Zmiana postawy banków pozwoliła na zaspokojenie popytu na kredyty osób, które we wcześniejszych latach zostały odrzucone jako potencjalni kredytobiorcy. Doprowadziło to podziału rynku kredytów na segmenty: prime, Alt-A i subprime. Subprime mortgages sa to kredyty udzielane osobom spełniającym przynajmniej jedno z kryteriów: zła historia kredytowa (opóźnienia w spłacie kredytów, bankructwo), niski scoring kredytowy lub wysoka wartość wskaźnika debt-to-inco$m e$, brak lub niepełna historia kredytowa ${ }^{56}$. Udział kredytów subprime $\mathrm{w}$ całym rynku kredytów hipotecznych wzrósł z 8\% w 2002 r. do 20,1\% w 2006 r. ${ }^{57}$

W okresie boomu kredytowego nastapił gwałtowny wzrost liczby udzielanych kredytów hipotecznych oprocentowanych według zmiennej stopy procentowej (ARM - adjustible rate mortgages). Udział ich wyniósł w latach 2004-2006 blisko 35\% udzielonych w tym okresie kredytów hipotecznych ${ }^{58}$. W. Nawrot przytoczyła dane, zgodnie z którymi w 2007 r. $80 \%$ kredytów zaciagniętych w sektorze subprime miało oprocentowanie typu ARM ${ }^{59}$.

Załamanie się trendu wzrostowego cen nieruchomości i zacieśnianie polityki pieniężnej przez Rezerwę Federalną spowodowały wzrost liczby straco-

${ }^{56}$ M. Wydra, Doświadczenia Kanady i USA w trakcie obecnego kryzysu finansowego w obszarze ubezpieczeń kredytów hipotecznych, w: A. Szelagowska (red.), Wspótczesna bankowość hipoteczna, CeDeWu, Warszawa 2010, s. 252.

57 A. Bojanowska, op. cit., s. 21.

58 D. Baker, The housing bubble and the financial crisis, „Real-World Economics Review”, no. 46, 2008, s. 74-76.

${ }^{59}$ W. Nawrot, op. cit., s. 70. 
nych kredytów, tzw. defaultów ${ }^{60}$. Udział niespłaconych kredytów hipotecznych udzielonych pod nieruchomości mieszkalne (niekomercyjne) przedstawiono na wykresie 3 . W $2004 \mathrm{r}$. zagrożonych było tylko niewiele ponad 1\% kredytów hipotecznych. W 2007 r. udział ten przekroczył 3\%, a w 2008 r. $-6 \%$.

Nadmierna ekspansja kredytowa banków komercyjnych wywołana była rosnącym apetytem na ryzyko ze strony banków komercyjnych, nieustannie poszukujacych nowych możliwości zwiększenia zysków. Lekkomyślność instytucji finansowych spotęgowana była błędami w zarządzaniu, gdyż system motywacyjny skłaniał zarządzających do poszukiwania krótkookresowych zysków za cenę osłabienia długookresowego bezpieczeństwa. Dążenie to wyraziło się również w podejściu do finansowania działalności bankowej.

\section{Wykres 3}

Udział niespłaconych kredytów hipotecznych (w \%)

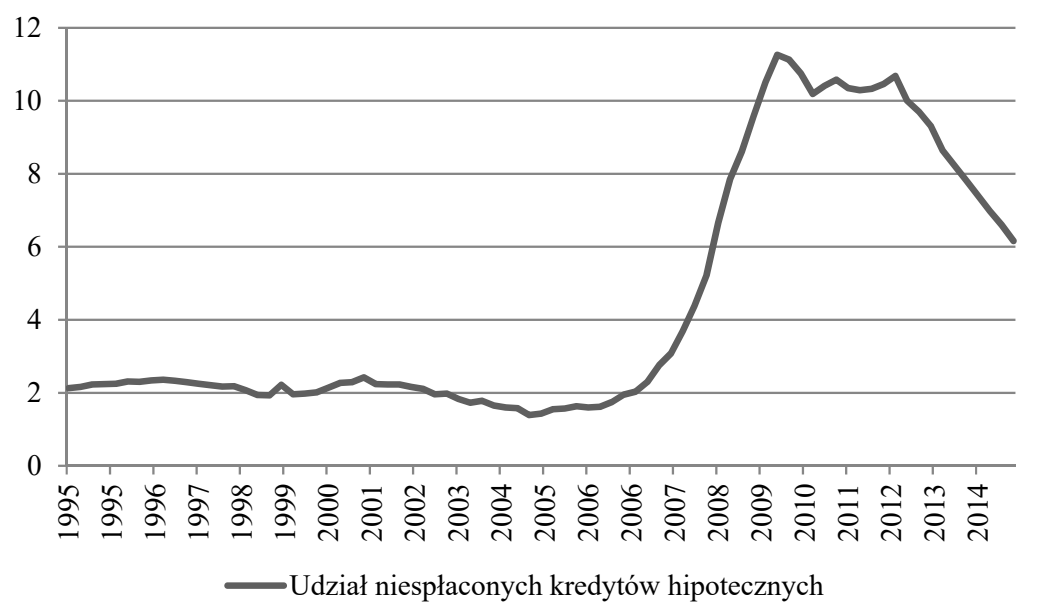

Źródło: opracowano na podstawie https://research.stlouisfed.org/fred2 [dostęp: 8.10.2016].

Wartość zadłużenia obywateli USA ponownie znajduje się w trendzie rosnącym, jednak udział niespłaconych kredytów hipotecznych zmalał w 2016 r. do poniżej $5 \%$, czemu niewątpliwie sprzyjają niskie stopy procentowe utrzymywane przez Rezerwę Federalną. Trudno oczekiwać, że krótkowzroczna polityka banków komercyjnych w zakresie poszukiwania zysków zmieni się, Pozytywne zmiany, które zaistniały po kryzysie, wynikają jednak ze wzmocnienia roli nadzoru i rozwinięcia zasad dotyczących wymogów kapitałowych uzależnionych od poziomu podejmowanego ryzyka. Dalsze działania powinny być podjęte w kierunku powstrzymania nadmiernej ekspansji kredytowej na rynku amerykańskim.

${ }^{60}$ Default - sytuacja braku spłaty kredytu lub, w szerszym znaczeniu, niedotrzymania warunków umowy kredytowej. 


\section{POLITYKA FINANSOWANIA DZIALALNOŚCI BANKÓW - WYKORZYSTANIE SEKURYTYZACJI I DŹWIGNI FINANSOWEJ}

Oprócz ryzykownej polityki kredytowej banki stosowały również ryzykowną politykę związaną z finansowaniem działalności. Dążąc do zwiększenia rentowności zaangażowanego kapitału, banki inwestycyjne wykorzystywały możliwości dźwigni finansowej, natomiast banki komercyjne zaangażowały się w proces sekurytyzacji. Za wzrost skali stosowania sekurytyzacji odpowiada nowelizacja ustawy CRA z 1995 r., która pozwoliła bankom na wykorzystanie tego procesu $\mathrm{w}$ odniesieniu do ryzykownych kredytów ${ }^{61}$. Uchwalenie w 1999 r. Gramm-Leach-Bliley Act wywołało daleko idącą deregulację sektora finansowego, której towarzyszyła fala fuzji i przejęć. W konsekwencji powstało wiele gigantycznych instytucji finansowych działających na różnych polach bankowości ${ }^{62}$. Ostatecznie w kwietniu 2004 r. zniesiono ograniczenie współczynnika lewarowania w bankach inwestycyjnych ${ }^{63}$.

Ryzykowne działania w obszarze finansowania miały więc dwojaka przyczynę. Sprzyjającemu otoczeniu prawnemu towarzyszyły okoliczności związane z wzrostem konkurencji w sektorze bankowym. Wynikające z polityki pieniężnej Rezerwy Federalnej obniżenie średniego oprocentowania kredytów na rynku, a zarazem marży banków, ograniczyło zyski osiagane przez te instytucje. Aby utrzymać oczekiwany przez inwestorów poziom zysku przypadającego na kapitał własny, banki zaczęły stosować lewarowanie dużo intensywniej niż wcześniej. Również powszechny trend maksymalizowania krótkoterminowych stóp zwrotu, sprzyjających wzrostowi cen akcji spółki na giełdzie, obją swoim oddziaływaniem banki. Jak podkreślił A. Leijonhufvud, wzrost konkurencji między bankami pchał je w trzech kierunkach: zwiększania dźwigni finansowej, inwestowania w bardziej ryzykowne aktywa przynoszące wyższy zwrot i finansowania się zobowiązaniami krótkoterminowymi o niższym oprocentowaniu ${ }^{64}$.

Banki komercyjne objęte wymogiem utrzymywania kapitału własnego w wysokości 8\% ważonych ryzykiem aktywów mogą operować z poziomem dźwigni finansowej (relacji aktywów do kapitału) wynoszacym 12. Przy poziomie dźwigni wynoszącym 30 strata $3 \%$ wartości aktywów może wywołać niewypłacalność instytucji. Jak podał Marcin Gruszczyński, w 2007 r. współczynnik lewarowania pięciu największych banków inwestycyjnych (Goldman Sachs, Merill Lynch, Lehman Brothers, Bear Stearns i Morgan Stanley) wynosił między 25 a $33^{65}$. Stosowanie wysokiej (wynoszacej ok. 32) dźwigni finansowej było jedną z głównych przyczyn upadku banku inwestycyjnego Lehman

${ }^{61}$ W 1997 r. First Union Capital Markets i Bear Stearns przeprowadziły pierwszą publiczną sekurytyzację portfela kredytów subprime, udzielonych na podstawie CRA, na kwotę 385 mln USD (W. Nawrot, op. cit., s. 73).

${ }^{62}$ H. Żywiecka, Niestandardowe działania banków centralnych w warunkach globalnego kryzysu finansowego, CeDeWu, Warszawa 2013, s. 293.

${ }^{63}$ M. Gruszczyński, Kryzysy walutowe, bankowe $i$ zadłużeniowe $w$ gospodarce światowej, CeDeWu, Warszawa 2013, s. 126.

${ }^{64}$ A. Leijonhufvud, op. cit., s. 3.

${ }^{65}$ M. Gruszczyński, op. cit., s. 126. 
Brothers $^{66}$. Z wysokiej dźwigni finansowej korzystały również Northern Rock, UBS, Deutsche Bank i Barclay's ${ }^{67}$.

Mechanizm dźwigni finansowej funkcjonuje w pewnym stopniu procyklicznie. Proces delewarowania może wynikać ze zwiększenia kapitału własnego lub spłacenia długu. Przyciagnięcie inwestora, który zainwestuje kapitał, jest trudne, gdy zachodzą watpliwości odnośnie do płynności i wypłacalności podmiotu. Środki konieczne do spłaty długu moga pochodzić ze sprzedaży aktywów lub z bieżących nadwyżek operacyjnych. Jeśli banki wykorzystają dochody odsetkowe i z rat kredytów do spłaty własnych długów, a nie do udzielania kolejnych kredytów, to zmniejszenie akcji kredytowej wywoła recesję, która jeszcze pogorszy sytuację wyjściową banku. Z kolei sprzedaż aktywów przez jeden bank powoduje, że spadająca cena tych aktywów odbija się w bilansach pozostałych banków. Pozytywne sprzężenie zwrotne oznacza, że próby ograniczenia długu zwiększają realne zadłużenie. Wahania poziomu dźwigni finansowej wzmacniają niestabilność w gospodarce ${ }^{68}$.

Na przełomie XX i XXI w. upowszechnił się model działalności bankowej o nazwie originate-to-distribute, dzięki któremu banki mogły uwolnić środki zaangażowane w aktywa pochodzące z kredytów, przerzucić ryzyko kredytowe na inne instytucje i udzielać następnych kredytów. D. Rosati przytoczył opinię, zgodnie z którą uważano, że choć model ten zmniejsza przejrzystość systemu i utrudnia wycenę ryzyka, to jednak poprawia alokację ryzyka, zapewnia większą efektywność systemu finansowego i wzmacnia jego odporność na szoki ${ }^{69}$.

Stosowanie przez banki sekurytyzacji było dla nich korzystne, gdyż pozwalało na ${ }^{70}$ : bieżące zarządzanie portfelem kredytów, bez konieczności przetrzymywania ich do terminu zapadalności; poprawienie wskaźników płynności, wypłacalności i adekwatności kapitałowej; pozyskanie taniego źródła dalszego finansowania akcji kredytowej; dywersyfikację źródeł finansowania i pozyskanie nowych inwestorów; dopasowanie terminów zapadalności długoterminowych aktywów i pasywów, przez emisję długoterminowych pasywów w formie instrumentów finansowych; odseparowanie ryzyka kredytowego (niebezpieczeństwa niespłacenia kredytu przez dłużnika) od banku.

Definicja uwzględniająca charakterystykę sekurytyzacji aktywów bankowych określa ją jako proces polegający na odpowiednim wyselekcjonowaniu puli (portfela) aktywów bankowych i przekształceniu go w papiery wartościowe zabezpieczone strumieniami pieniężnymi generowanymi przez te aktywa i sprzedawane inwestorom ${ }^{71}$.

${ }^{66}$ M. Banajski, Upadtość banku inwestycyjnego Lehman Brothers, w: P. Masiukiewicz (red.), Międzynarodowe bankructwa $i$ afery bankowe, SGH Oficyna Wydawnicza, Warszawa 2009, s. 150.

${ }^{67}$ M. Banajski, op. cit., s. 110 i 126; Ch. Goodhart, op. cit., s. 10-11.

68 A. Leijonhufvud, op. cit., s. 3-4.

${ }^{69}$ D. Rosati, op. cit., s. 321.

70 A. Berlik, Specyfika transakcji sekurytyzacyjnych przeprowadzanych w Polsce, w: W. Ronka-Chmielowiec, K. Jajuga (red.), Inwestycje finansowe i ubezpieczenia-tendencje światowe a polski rynek, Wyd. AE we Wrocławiu, Wrocław 2007, s. 39-40; M. Bartkowiak, K. Echaust, Instrumenty pochodne: wprowadzenie do inżynierii finansowej, Wyd. UEP, Poznań 2014, s. 223.

${ }^{71}$ M. Kalasińska, Sekurytyzacja aktywów bankowych, ZBP, Warszawa 2007, s. 10. 
W procesie sekurytyzacji udział biora: aranżer, podmiot specjalnego przeznaczenia (SPV - Special Purpose Vehicle), inwestorzy oraz agencje ratingo$\mathrm{we}^{72}$. Aranżer, najczęściej bank, wyodrębnia z puli udzielonych kredytów portfel tych aktywów charakteryzujący się m.in. zróżnicowaniem geograficznym, odpowiednią homogenicznością rodzaju aktywów i przewidywalnością wpływów ${ }^{73}$. Zostają one sprzedane do spółki celowej, np. funduszu sekurytyzacyjnego. Takie podmioty funkcjonowały jako instytucje parabankowe, więc nie były ograniczone wymogami kapitałowymi. Zakup puli kredytów SPV finansowały emisja papierów wartościowych zabezpieczonych tymi aktywami. Emisja podlegała ocenie dokonywanej przez agencje ratingowe. Wysoka ocena poprawiała atrakcyjność danego waloru. W wyniku odseparowania ryzyka papierów wartościowych od kondycji finansowej aranżera i odpowiedniej konstrukcji instrumentów ocena mogła być wysoka, nawet jeśli emisja oparta była na portfelu kredytów subprime. Zakupu wyemitowanych papierów wartościowych dokonywało wiele instytucji finansowych zachęconych wysokim ratingiem.

Axel Leijonhufvud celnie wskazał, że próba przeniesienia zasad korzystnych dla jednego podmiotu na cały system finansowy okazała się błędem ${ }^{74}$. Pojedyncza instytucja powinna dywersyfikować ryzyko dla zachowania bezpieczeństwa, jednak gdy pozwoli się wszystkim podmiotom tworzacym system finansowy dywersyfikować ryzyko bez regulacji nadzorczych, narasta sieć powiązań między podmiotami. Zaburzenie wywołane w jednej instytucji szybko dotknie cały system. Namnażanie instrumentów i rozproszenie zaangażowania na rynkach wywołało sytuację, w której „wszystkie jajka znalazły się w tym samym koszyku".

Również w tej kwestii motywacje, które skłaniały banki komercyjne do podejmowania wymienionych praktyk, nie ustały w minionym dziesięcioleciu. Jednakże działalność banków została w ostatnich latach poddana znacznie większemu nadzorowi. Reguły Bazylei III ograniczają możliwość stosowania nadmiernej dźwigni finansowej i kładą jeszcze większy nacisk na zapewnienie płynności finansowej dzięki wprowadzeniu restrykcyjnych wymogów adekwatności kapitałowej uzależnionej od poziomu podejmowanego ryzyka. Zmiany w tej kwestii wprowadziła również ustawa Dodda-Franka z 2010 r.

\section{INŻYNIERIA FINANSOWA I AGENCJE RATINGOWE}

Wraz z upowszechnianiem się procesu sekurytyzacji powstało wiele nowych kredytowych instrumentów pochodnych. Próby kontroli rynku derywatów w Stanach Zjednoczonych, inicjowane przez Commodity Futures Trade Commision, nie powiodły się. W 2000 r. uchwalono Commodity Futures Mo-

72 I. Raczkowska, Sekurytyzacja wierzytelności bankowych: podstawowe zagadnienia prawne, Konieczny i Kruszewski, Warszawa 2001, s. 31-39.

${ }^{73}$ M. Kalasińska, Sekurytyzacja wierzytelności hipotecznych na światowych rynkach, w: A. Szelagowska (red.), Współczesna bankowość hipoteczna, CeDeWu, Warszawa 2010, s. 106.

${ }^{74}$ A. Leijonhufvud, op. cit., s. 5. 
dernization Act - ustawę, która zabraniała regulacji instrumentów pochodnych ${ }^{75}$. Były prezes Rezerwy Federalnej A. Greenspan był, już od 1994 r., jednym z przeciwników zaostrzania regulacji na rynku derywatów ${ }^{76}$. Spadająca wartość ryzykownych papierów wartościowych spowodowała, że straty dotknęły nie tylko te instytucje, które bezpośrednio udzielały ryzykownych kredytów hipotecznych, ale również podmioty, które posiadły tzw. toksyczne aktywa w swoich bilansach.

W zależności od rodzaju należności bankowych podlegających sekurytyzacji papiery wartościowe emitowane w tym procesie nazywano: MBS (zabezpieczone kredytami hipotecznymi) lub ABS (zabezpieczone innymi rodzajami kredytów) ${ }^{77}$. Bardziej skomplikowaną formę miały instrumenty charakteryzujące się podziałem inwestorów na tzw. transze, które różni priorytet spłaty kapitału - CMO, CDO lub $\mathrm{CLO}^{78}$.

Zanim doszło do gwałtownego spadku wartości papierów wartościowych zabezpieczonych hipotecznie, rynek ten rozwijał się bardzo dynamicznie. Dla przykładu wartość rynku MBS wzrosła z 95 mld USD w 2001 do 507 mld USD w 2005 r., a udział kredytów subprime, które podlegały sekurytyzacji, zwiększył się z 50\% w 2001 do $81 \%$ w 2005 r. ${ }^{79}$ Również wartość wyemitowanych ABS charakteryzowała się trendem rosnacym - w 2001 r. wyniosła 383 mld USD, a w 2006 - 1253 mld USD. Jednak w 2008 r. emisja wyniosła już tylko 163 mld USD ${ }^{80}$.

Wycena papierów zabezpieczonych hipotecznie jest bardziej skomplikowana niż w przypadku standardowych instrumentów finansowych. Brak odpowiednich modeli wyceny oznacza, że dokonywana jest ona zazwyczaj metodą symulacji Monte Carlo ${ }^{81}$. Agencje ratingowe popełniły ponadto wiele, świadomych bądź nie, błędów. Należały do nich: bazowanie na zbyt krótkich szeregach czasowych, przekonanie, że dywersyfikacja może wyeliminować ryzyko niewypłacalności pojedynczego kredytobiorcy, niedoszacowanie ryzyka systemowego, niedoszacowanie prawdopodobieństwa zdarzeń rzadkich i błędne przekonanie o możliwości ekstrapolacji trendu wzrostowego na rynku nieruchomości ${ }^{82}$.

Problemy związane z wyceną wpłynęły na jakość dokonywanej przez agencje ratingowe oceny. Transze o wysokim priorytecie spłaty (zwane senior) otrzymywały oceny AAA, dużo wyższe niż kolejne w spłacie transze (zwane mezzaine i equity), nawet jeśli sekurytyzowanymi należnościami były kredyty subprime. CDO kupowały więc europejskie banki, fundusze inwestycyjne i emerytalne. Poziom zabezpieczenia w kapitale własnym banku uzależniony

${ }^{75}$ M. Gruszczyński, op. cit., s. 124.

76 E. Andrews, op. cit.

77 A. Berlik, op. cit., s. 39.

${ }^{78}$ M. Kalasińska, Sekurytyzacja wierzytelności..., s. 109; K. Jajuga, Instrumenty finansowe zabezpieczone hipotecznie, w: A. Szelagowska (red.), Współczesna bankowość hipoteczna, CeDeWu, Warszawa 2010, s. 98-101.

${ }^{79}$ A. Bojanowska, op. cit., s. 21.

${ }^{80}$ M. Kalasińska, Sekurytyzacja wierzytelności..., s. 113.

${ }^{81}$ K. Jajuga, op. cit., s. 101.

82 A. Szyszka, op. cit., s. 22-23. 
jest od oceny ryzyka związanego z danym walorem. Dlatego ocena ratingowa AAA pozwalała instytucjom ograniczonym nową umowa kapitałową zabezpieczać zakup CDO niewielką ilością kapitału, co wpływało na zyskowność inwestycji ${ }^{83}$.

Niektórzy ekonomiści wskazuja, że kryzys finansowy dowiódł fiaska agencji ratingowych ${ }^{84}$. Duże znaczenie tych instytucji wynika w znacznej mierze $\mathrm{z}$ faktu, że systemy nadzoru nad rynkiem finansowym opierają się na ocenach dokonywanych przez agencje. Krytyka tych podmiotów, zgłoszona już w 2003 r., wynika z konfliktu interesów, braku przejrzystości ocen opracowanych przez amerykańskie agencje oraz zarzutu, że agencje wzmacniają bieżące negatywne trendy rozwojowe - działaja procyklicznie. Konflikt interesów w działaniu agencji ratingowych polega na tym, że są one opłacane przez zleceniodawców, których produkty finansowe sa przez nie oceniane. Agencje doradzały swoim zleceniodawcom oraz współdziałały w opracowywaniu nowych instrumentów finansowych, które następnie oceniały. Rynek ten został ponadto zdominowany przez trzy agencje (Moody's, Standard \& Poor's i Fitch) ${ }^{85}$.

Rynek papierów zabezpieczonych aktywami typu ABS znacząco zmalał w konsekwencji kryzysu finansowego. Dane dotyczące emisji papierów typu MBS pokazuja jednak, że nadal jest to popularny mechanizm transferu ryzyka. Aczkolwiek pewne regulacje dotyczące papierów wartościowych wprowadziła ustawa Dodda-Franka, brak jest dalej posuniętych zmian, które wprowadziłyby większą transparentność na rynku instrumentów finansowych. Mimo podjęcia kroków mających na celu kontrolę działalności agencji ratingowych, nie zmienia to faktu, że podjęte w ostatnich latach reformy jeszcze zwiększyły rolę ocen przez nie nadawanych w procesie zarządzania ryzykiem w bankach. Nie zniwelowało to najważniejszych problemów: konfliktu interesów wewnątrz agencji bądź koncentracji rynku. W Europie nadzór nad rynkami finansowymi oraz agencjami ratingowymi przypadł $\mathrm{w}$ roli nowo utworzonemu podmiotowi - ESMA (European Securities \& Market Authority), który stanowi część europejskiego systemu nadzoru finansowego, który rozwijany jest w reakcji na kryzys finansowy.

\section{PODSUMOWANIE}

Pojawienie się kryzysu finansowego spowodowane było nałożeniem się wielu czynników, do których należały: ekspansywna polityka pieniężna SRF $\mathrm{w}$ sytuacji narastania globalnych nierównowag, trend wzrostowy na amerykańskim rynku nieruchomości i liberalna polityka kredytowa banków komercyjnych, wspierana przez rozwój nowoczesnych instrumentów finansowych

\footnotetext{
${ }^{83}$ A. Sławiński, Przyczyny..., s. 43.

${ }^{84}$ A. Szyszka, op. cit., s. 22.

${ }_{85}$ T. Kaczmarek, Agencje ratingowe jako źródto niestabilności globalnych rynków finansowych, w: L. Oręziak, D. Rosati (red.), Kryzys finansów publicznych: przyczyny, mechanizm, drogi wyjścia, Oficyna Wydawnicza Uczelni Łazarskiego, Warszawa 2013, s. 143-144.
} 
wywodzących się m.in. z sekurytyzacji. Kryzys miał również wiele przyczyn natury psychologicznej.

W mechanizmie rozwoju sytuacji wyróżnić można pewną sekwencję zdarzeń. Spadki cen nieruchomości i wzrost stóp procentowych spowodowały wzrost ilości niespłaconych kredytów hipotecznych. Nastapiło zachwianie zaufania do papierów wartościowych powstałych w procesie sekurytyzacji, więc ich ceny spadły. Spadek cen tych instrumentów finansowych wpłynął na konieczność dokonania odpisów z tytułu spadku wartości aktywów. Instytucje finansowe uznały, że niepewność co do sytuacji finansowej ich kontrahentów jest wysoka i zaprzestały wzajemnie udzielać sobie kredytów. Utrudnienia w finansowaniu uniemożliwiły dokapitalizowanie, które było konieczne ze względu na stosowanie dźwigni finansowej. Instytucje stały się więc niewypłacalne. W ten sposób pęknięcie bańki na rynku nieruchomości doprowadziło do kryzysu zaufania w sektorze bankowym, niewypłacalności tego systemu i upadku wielu instytucji.

W momencie gdy doszło do pierwszych zaburzeń na rynkach finansowych, inwestorzy i decydenci nie zdawali sobie jeszcze sprawy z tego, jak wielkie i globalne konsekwencje będa miały te wydarzenia. Wybuch kryzysu finansowego stał się fundamentalną przyczyna powszechnej dyskusji nad koniecznością zmiany podejścia do kontroli i nadzoru sektora finansowego, zarówno w USA, jak i w Unii Europejskiej. Nie zdarzyło się to po raz pierwszy, że praktyka wyprzedza teorię. Teoria dopiero po pewnym czasie będzie podążać za zmianami, jakie zachodzą na rynkach finansowych.

dr Hanna Kołodziejczyk

Uniwersytet Ekonomiczny w Poznaniu

hanna.kolodziejczyk@ue.poznan.pl

\section{THE ORIGINS OF THE SUBPRIME MORTGAGE CRISIS - A DECADE'S PERSPECTIVE}

\section{Summary}

In 2007, the US subprime mortgage industry collapsed into a financial turmoil. The analysis presented in this paper aims at identifying the sources of the subprime mortgage crisis. In an attempt to present a structured overview the following factors have been taken into account: the global imbalances and the Federal Reserve's policy during the years 2001-2007; the conditions on the real estate market and the housing policy in the USA; the developments on the financial markets and their supervision; commercial banks' credit policy and their risk appetite; banks' sources of funding - the use of securitisation and leverage; the behaviour of credit rating agencies and financial engineering. 
